\title{
Improving Non-Majored Students' Fluency in the English Speaking Skill in the Online Environment via Ms-Team
}

\author{
Thach Thi Ngoc Phan ${ }^{1 *}$ - Duyen Thi Nhu Huynh ${ }^{1}$
}

\author{
${ }^{1}$ Language Institute, Van Lang University, Vietnam \\ *Corresponding author. Email: ngocthach197@gmail.com
}

\begin{abstract}
Teaching the speaking skill for non-majored students in an online environment with large class size is a challenge for EFL teachers. Therefore, this study aims at exploring English speaking difficulties in the online environment in terms of interaction and concentration in the relationship with the students' speaking fluency. The study involved about 70 non-English majors at Van Lang University in answering a questionnaire.
\end{abstract}

The results revealed that although students were taught the prescribed syllabus of balancing integrated skills, their teachers still had the trend of avoiding (or lessen the time) teaching the speaking skill online. The results further indicated that the learning of speaking online was passive, mostly because of the students' lack of input due to their low level and their lack of interaction with their teacher and peers. Findings are hoped to contribute to a better understanding of non-English majors' speaking fluency difficulties in the online EFL context.

Then, a solution of adopting Microsoft Whiteboard, which is already integrated with Microsoft Teams, is suggested to partly help enhance the teacher- students' interaction, the most frequent and typical interaction, as a method to increase the students' fluency when learning online.

Keywords: non-English major, speaking fluency, online learning, big size class, low level.

\section{INTRODUCTION}

Fluency in English speaking is often defined as an automatic procedural skill [13], or the features which give a speech the qualities of being natural and normal, including native-like use of pausing, rhythm, intonation, stress, rate of speaking, and use of interjections and interruptions [33], or the ability to produce the second language with native-like rapidity, pausing, hesitation, or reformulation [20]. According to those definitions, the students can achieve fluency when they devote time to practice, fulfill the assessment needs, and repeat the limited time constraint [12.28].

The digital world and its learning benefits cross and embrace all generations and wealth divides [35].
Therefore, online learning in speaking English is not only for personal's convenience but also the worldquest. Therefore, teaching and learning English speaking skills online is a quest in any university program. This is achievable but needs many efforts since the students face many troubles in the online learning environment. To build the students' fluency ability in the online environment, especially with low or medium-level students in a big class size, Microsoft Whiteboard, which is already integrated in Microsoft Teams (initially distributed collaboration on shared projects, and now been brought into play for teaching and learning under the sudden shift to online learning trend in the initial COVID-19 period [19] is suggested as one of the effective strategies that can partly help enhance the teacher- students' interaction- the frequent kind of interaction in any online lessons. 


\section{LITERATURE REVIEW}

\section{Online learning}

\section{Advantages}

There are many benefits that online learning brings, which is mentioned in much scientific research within the CLT. The first outstanding advantage is that the students actively participate in the lesson because online learning can enhance learners' cognitive abilities and problem-solving skills [10]. Secondly, online learning is beneficial because it can reduce the students' anxiety and shyness when they shape their learning in their own pace [6.25.41]. Moreover, another positive learning outcome is a stronger sense of community among students and a reduction in withdrawal or failure [31], which means that they can help each other reach their targets. Moreover, especially with higher education, online learning is more successful when the students' autonomy is stably formed as there is a tight connection between autonomous learning and online learning success [10.40]. Next, due to online learning's mobile nature, students can absorb more information when they are at their best and reread when they need it [3]. In general, there are many benefits that online learning can bring to the students, especially in their meta-cognition, their problem-solving skill in relation to their own psychological conditions, and their autonomy.

\section{Disadvantages}

Regardless of the possibility of accessing the online mode learning in terms of costs and their geological conditions, the online mode itself also has some defeats. Firstly, there is also a need for the teacher's instruction as "a prevalent issue for those institutions that plan to continue offering instruction at a distance" for the students to achieve their best result in learning [23]. Secondly, the students' readiness when entering the online learning environment is an important factor contributing to online learning success [2.9.17.18.27.54.56]. When excluding the possibility to afford online learning, the readiness relates to their learning background, their devoting time for learning, the teacher's instructions, and task complexity, etc. Thirdly, despite the advantages of online learning, it is proved that there is no significant difference in the learning outcomes for the traditional face-to-face format versus mediated instruction [26.34]. However, although the conclusion drawn from Thomas Russell is famous in the field, there are still many criticisms, one of which is that the majority of the original studies have poor methodology when lacking control groups, random assignment, experimental controls for confounding variables, and little to no discussion of attrition [31]. Despite being similar to Tomas Russell's works in having the same conclusion, Bernard et al. [5] added that there are better learning outcomes in the traditional format for activities that have to be done simultaneously and better outcomes in the mediated distance format for activities that can be done at various times. To sum up, learning online only improves the students' level in certain conditions compared to campus learning, one of which is to increase students' motivation and interaction.

\section{Students' motivation}

According to Lamb [24], autonomy has both awareness and reflection features. Both the two main kinds of students' motivation (Integrative- the motivation is referring to "an openness to identify at least in part with another language community" [29], and instrumental motivation, the desire from which learners to get a social and economic reward, like getting a good salary or getting into college [29], correlates significantly to the students' speaking competence [15]. Within the classroom's impact, the teacher can mostly increase the students' instrumental motivation by encouraging the students' interaction and meaning negotiation during classes because the students who interact and speak achieve better oral skills in most cases than those who always keep silent [30]. In general, the more students feel motivated, the more successful they are in completing online courses [14].

\section{Students' Concentration and Interaction}

Interaction is considered an important element in any educational program, even online or on-campus; Simpson, O. [42] stated that concentration is one of the study problems in the learning skills. In the offline class, participants experienced increased engagement on the high's condition, and the balanced perceived challenge of the task and their skills were high and in balance, the relevant instruction, and the controllable learning environment [38]. In the online environment, because of the nature of the online learning model, in which the teacher and the students can not directly face to face, "mind-wandering frequently occurs in the classroom and while studying" [47]. Therefore, interaction is a key variable in learning and satisfaction with distance education courses [53]. In the online learning environment- a subpart of Distance Education, regular and substantive interaction between the students and the instructor can be supported synchronously or asynchronously [42]. 


\section{METHOD}

\section{Study design}

The study was designed as quantitative research in which the simple random sampling scheme randomly sampled the participants. The data, which is collected one time only at a purposeful time (after the students' experience with 100 percent offline, 100 percent online learning, and the mixture of both the two learning mode), is served as a mean to know the students' current fluency's level in the English speaking skill concerning their online learning's conditions.

\section{Participants}

The participants are non-English majored students at Van Lang University, Vietnam.

\section{Setting}

The students have just completed three integrated English courses with a class size of around forty students in one class. The first course was carried out in the offline learning mode with forty-five in-class periods and nine autonomous but supervised learning periods. The second course was taught in the online learning mode with forty-five periods and nine autonomous but supervised learning periods. The third course is a mixed course with offline and online learning modes with forty-five periods in total and nine autonomous but supervised learning periods.

\section{Procedure for data collection}

The online questionnaire, which was delivered randomly to sixty-four students in two different classes, is delivered only one time, and at the end of the third course,

\section{Measurements of endpoints}

The primary endpoint is to find out the online learning conditions in the co-relation with the students' level and motivation, which affect the fluency in the students' English speaking skill. The second endpoint is increasing the students' fluency in English speaking ability during online learning.

\section{RESULTS}

\section{The students' speaking level in general}

In this survey, the participants self-evaluate their English speaking ability diversely, ranging from "very good" to "very bad". Besides, the data in Figure 1 also shows the downward trend of the speaking level because the participants majorly have "Medium" (with
60.9 percent) or "Bad" (with 20.3 percent) English proficiency in accordance with the expected level of proficiency stated in the course's evaluation.

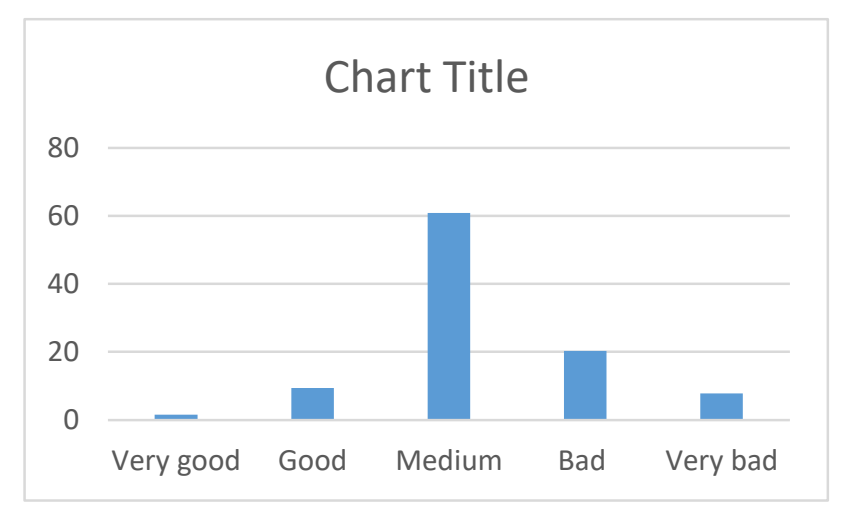

Figure 1: The students' speaking ability

\section{The students' fluency in the English speaking skill}

The student's speaking fluency in Figure 2, which is consistent with the data in Figure 1, still shows the descending trend of the student's speaking levels.

For example, the total percentages of the fluency level of "medium" and "low" are nearly the same percentage of the general speaking ability in figure 1 . However, it also reveals that fluency is harder to achieve to a certain number of the students in the survey because the number of students who has a "bad" fluency level (31.9 percent) is higher than the number of those in the general speaking skill (20.3 percent) in figure 1 .

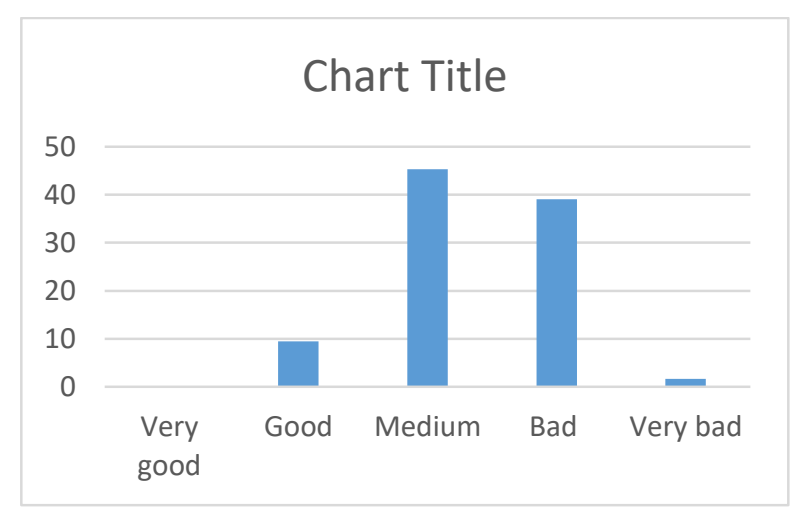

Figure 2: The students' fluency in the English speaking skill

\section{The students' strength and weaknesses}

Different students will have different strengths and weaknesses, but the following points, as shown in Figures 3 and 4, are outstanding. The majority of the students lack vocabulary items for speaking fluently. As shown in two figures 3 and 4, only 18 percent of the students consider vocabulary as their strength in speaking. At the same time, nearly half of them (43.8 
percent) admit that vocabulary makes their speaking fluency worse. Secondly, the students' accuracy in speaking is at different levels. For example, the "use of grammar" is considered as the students' strength (26.6 percent), but it is also the students' weakness (with the other 25 percent). Also, pronunciation is in the same scenario. A third of the participants in the survey (29.7 percent) considered it their weaknesses, and half of them considered it their strength. The differences in the student's strength and weaknesses in their English also confirm that the participants in the survey are in the mix levels.

3. What is your strength in the English speaking skill? you can choose more than one answer

(Thế mạnh của bạn trong kỹ nảng noii Tiếng Anh là gị? bạn có thể chọn nhiếu đảp án)

64 responses

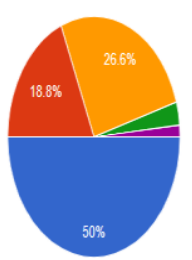

- Pronunciation (Phát àm)

- Vocabulary (Tư ṿ̛ng)

The use of Grammar (ş̉ dung önng cât

trüc ngî̉ phảp)

- Khóng có

- conn kém trong vièc nó

Figure 3: The students' strength

4. Which of the following prevents you from speaking English fluently? you can choose more than one answer (Những cản trở nào ảnh hưởng đến đọ̣ lưu loảt trong kỹ nảng nöi Tiếng Anh của bạn? bạn có thể chọn nhiếu đáp ản)

64 responses

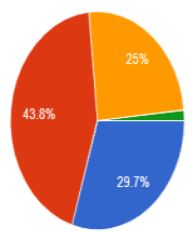

- Pronunciation (Phát ám)

- The use of Grammar (Sỉ dung oủng cát

trúc ngü pháp)

- Tư vung vià ngü pháp

Figure 4: The students' weaknesses

\section{The students' practicing the speaking skill online (in relation to the range of online speaking activities)}

\section{The students' practicing mode}

As shown in figure 5, the participants' online speaking practice balances with the offline in-class practice. 60.9 percent of the participants agree that their teachers set time during the online sessions for their English speaking practice. It shows that teachers follow the syllabus, which is designed for integrated skills within each lesson. However, there is an emerging trend of the teachers' avoiding teaching speaking online as 32.8 percent of the participants' reports that they have speaking tasks mainly in offline classes
5. During the two semesters learning online and offline, When do you practice English speaking skill ? (Trong chương trinh học trực tuyến (có kết hợp trực tiếp) trong 2 học kỷ vửa qua , Khi nào bạn thực tập kỹ năng nói?) 64 responses

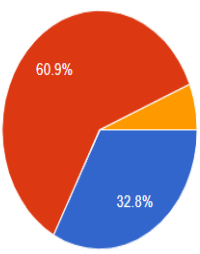

- Mainly in the offline class's activities (Chủ yếu là khi hoc trực tiếp trên lợp) - In both the offline and online activities
equally (Cà hoc truxc tuyến và turc tiếe

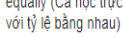

Mainly in the online class's activities (Chủ yếu là khi học trực tuêên)

Figure 5: The students' speaking practice's mode

\section{How the speaking skill is practiced.}

The students' actual online time to practice the speaking skill is not sufficient. In the offline classes, according to Siedentop \& Tannehill [37], the student's engagement in the speaking activities is influenced by the "Funnel effect" as they have to spend much time in the class for waiting, management and transition, receiving information, and the rest of less than $1 / 3$ of class time for allocated practice. It means that their actual English speaking time is deducted. In online classes, the students' actual English speaking practice is influenced even more seriously than offline ones. In this study, the speaking skill's practice is mainly through the channel of teacher-students interaction as 65.5 percent of the participants report that they have it as their online classes' main mode of practice speaking. However, in this study, the class size is high with around forty students in each class Therefore, within the limited time frame of the syllabus, with the big class size and the distracting feature of the online learning environment, the students' actual time for practice speaking is not enough.

As shown in figure 6, the online class's speaking time is also not effectively used. To be specific, around 43.8 percent of the participants admit that they practice speaking skills when learning online. It somehow shows the students' effort to improve their English speaking ability. However, despite the students' effort, it still brings just little effect with both the fluency and accuracy in the students' speaking since the majority of the students are not proficient enough to realize their mistakes and provide the self-correction as a result of their "medium" and "low" level of their English speaking ability. It does not mention only about 14.1 percent saying that they do oral discussion with their partners, which means that the majority of the participants do not have adequate peer interaction, especially of about 4.7 percent of the participants admitting that they say nothing during the speaking activities. The data shows that the teacher cannot interact with all the students simultaneously in the learning mode of the teacher- students' interaction. As 
a result, the students' online class time is not exploited effectively.

In general, the online speaking activities is not adequate and mainly passive, thus, not effectively even with the diverse speaking activities (very diverse: 14.1 percent, various 56.3 percent, medium (21.9 percent) as stated in figure 7 below)

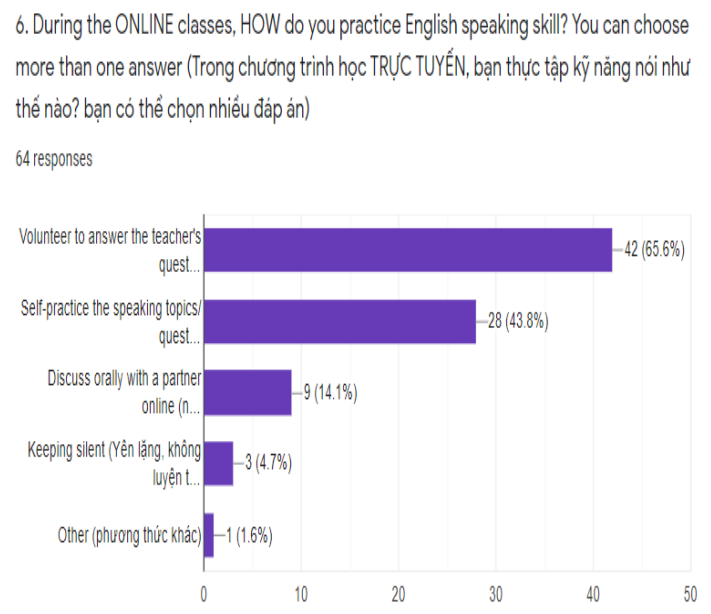

Figure 6: How the speaking skill is practiced

9. In your ONLINE curriculum, How do you feel about the English Speaking activities? (Trong chương trinh học TRỤC TUYẾN, bạn thấy các hoạt động speaking như thế nảo?) 64 responses

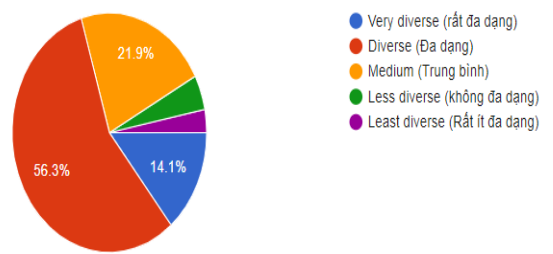

Figure 7: The range of the speaking activities

\section{The students' concentration and interaction when learning the speaking skill}

About the students' concentration, as in figure 8, the majority of the students states that their engagement in online learning is of the medium level (45.3\%). According to Vonderwell \& Zachariah [45], online learner participation and participation patterns are influenced by many factors: technology and interface characteristics, content area experience, student roles, and instructional tasks, and information overload. Therefore, the percentage of the student's concentration in this study can only be considered due to the combinations of many interrelated elements. However, the data also shows the positive trend of the students' concentration from medium (45.3 percent) to much (28.1 percent) to very much (17.2 percent). It means that most students have recognized the importance of concentration in the online environment. Generally, despite recognizing the importance of engagement, the students majorly concentrate at the medium level.

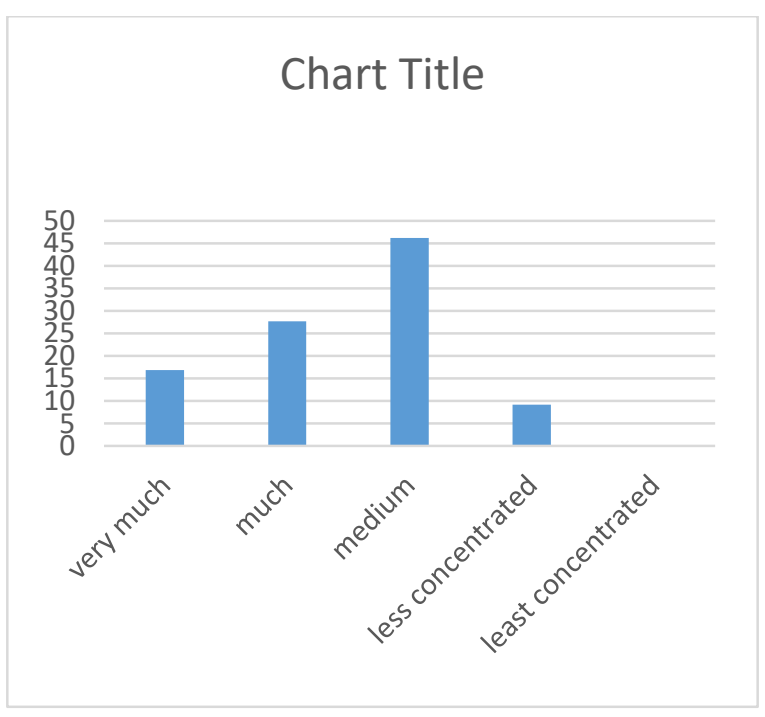

Figure 8: The students' concentration when learning the speaking skill

The data also shows that most of the students do not have adequate interaction about the students' interaction. According to Bernard et al. [5], those three types of interaction are important: among students, between the instructor and students, and between students and course content. In this survey, the participants state that their interaction is at the medium level (46.9 percent) or Less interactive (17.2 percent). It is similar to the ideas of Young [52] and Burdman [8] that E-learning lacks vital personal interactions, not only between learners and instructors but also among colleague learners.

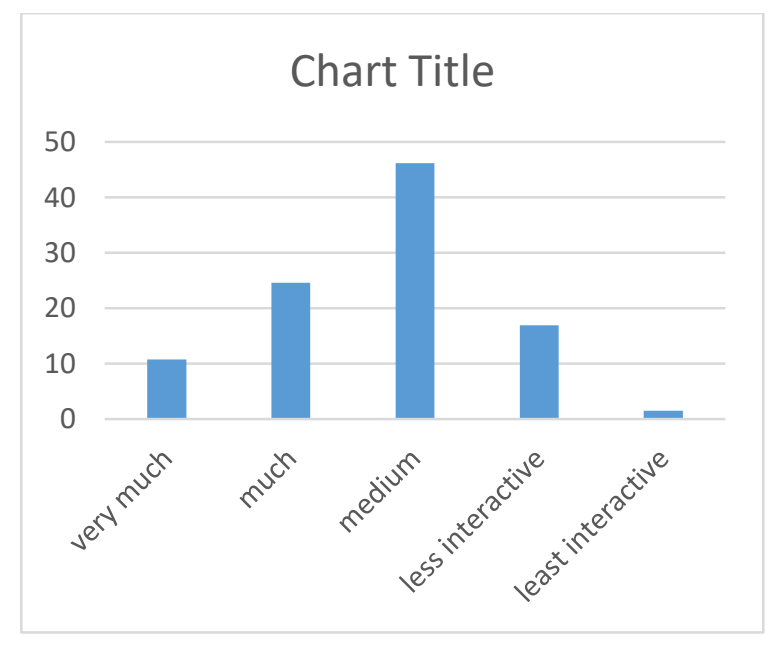

Figure 9: The students' interaction when learning the speaking skill

\section{Students' expectancy}

As stated in figure 10, the students expect to be equipped with more input and interaction. 


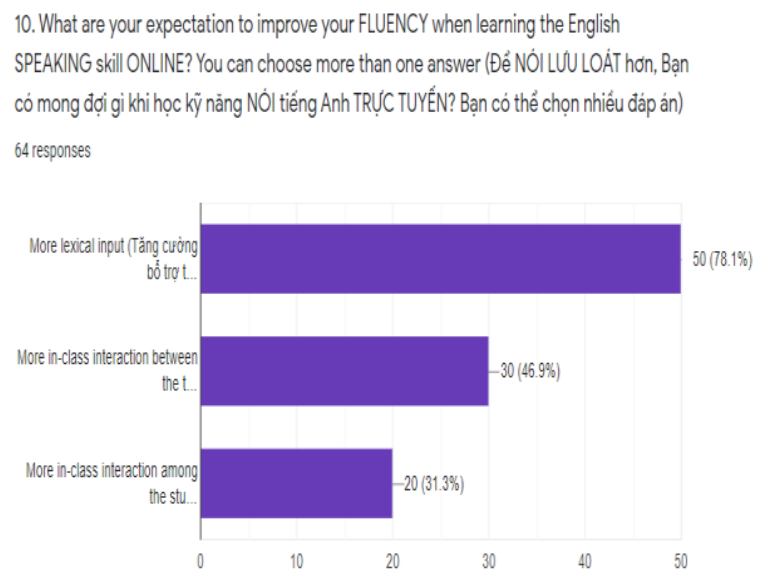

Figure 10: Students' expectancy

\section{DISCUSSION AND SUGGESTIONS}

The students' background is in the fluency ability mix level, mainly with the "medium" "low" ones. They have various problems regarding their pronunciation, grammar, and vocabulary before they fully learn in the online environment. The students do not have enough readiness, one of the decisive elements stated in the previous sessions, for learning online.

However, the students' input for the speaking skill, especially fluency, is shrunk because of two main reasons. Firstly, some of the teachers, the main contributor of the students' input, tend not to spend time for online speaking practice. Moreover, the learning of speaking online is passive because the student's effort and the online class's interaction are mostly at a "medium" level. As a result, although students received a certain amount of input when being taught the prescribed syllabus in which skills are balanced and integrated, due to their lack of concentration and interaction when practicing, they cannot proceed to convert the input into their intake, as input only become intake for language learning when it is consciously noticed [36]. Therefore, it requires very strong motivation and time management skills to reduce the effects of contemplation, remoteness, and lack of interaction and relation [1].

As analyzed above, one of the practical ways to increase the students' ability in speaking fluency is increasing the teacher- students' interaction - the most frequent means of teaching and learning in real-time online classes. As a result, when delivering the lessons in real-time online learning via the support of MsTeam- one of the most popular ways of lecturing nowadays, to diversify the lessons and boost the lessons' interaction as well as the students' concentration, the teachers often combine it with different soft-wares or online programs. However, Salmon, G. [35], whose book named "E-tivities" is famous worldwide, claimed that "many people will be unfamiliar with the software you choose to use". Therefore, within the limited time frame of the realtime online classes, instead of using too many apps, teachers are suggested adopting Microsoft Whiteboard in Teams to boost the student's learning of speaking skill visually in terms of interaction, concentration, and recall of vocabulary. As it has been confirmed in various research findings, the digital whiteboard is beneficial when integrated with Microsoft Teams [16.22.48.49.51]

In terms of interaction, Xu \& Moloney [49] claimed that students frequently interacted when involving in the manipulation of language elements. Firstly, the interaction is achievable because a real-time online classroom can easily be led to a more discussion-based meeting. Online classrooms are not one-way presentations anymore; instead, they become discussions that involve all members in the class, contributing valuable information and ideas because, together with the largest color ranges, Microsoft whiteboard has the best feature of an intelligent object recognition tool, which automatically improves or replaces hand-done drawings with clearer, more detailed versions [46]. Secondly, even when the teacher is delivering the lesson, interaction is also possible. Microsoft whiteboard tools offer in-app video conferencing and real-time collaboration features where teachers and students can work on the same canvas - an infinite one - and track each other's changes with real-time change previews and mouse tracking. Just like in a physical classroom where everyone interacts around a board, Microsoft Whiteboards allow teachers and students to repeat the experience of a physical whiteboard online and make it possible to increase the learning in class. Next, interaction can be enhanced by gamification through an interactive whiteboard. "Gamification" increases task engagement and decreases attrition [31]. Actively involving students as designers and digital game producers can boost concentration and engagement [50]. To be specific, teachers can create activities like quizzes or fun games for speaking (crossword puzzles, hangman, moving pictures, what's the difference) to make the online lessons more interactive and encourage students to use English more frequently. To find out the answer in the games, students have to interact and discuss with the others, in which the teacher can encourage them to use English as much as they can. It does not mean that gamification used in other softwares or online tools is inefficient, but when integrated with MS-Team, games are more user-friendly and less time-consuming for technical requirements.

In terms of the students' concentration, the teacher can keep track of students' learning process, and important details and ideas may be recorded quickly. An online whiteboard is primarily a collaboration tool 
that let class members make real-time notes, drawings, edits, and more together on a shared virtual whiteboard with online collaboration features. While the teacher can use it during lessons to visualize and simplify concepts and ideas for the students through writing or drawing, he/she can also get the students to contribute to the lesson right at that moment. When students realize that they understand the problem and contribute to the lesson, it is easier for them to be motivated and increase their concentration on teaching materials [32].

In terms of practicing using vocabulary, Oz [32] declared that the whiteboard helps students remember and retain what they learn for a long time. By encouraging students to use a mind map, concept map, flowchart, or graphic organizer to take down their notes, teachers can help improve their students' ability to absorb and recall information, which is a good way to study vocabulary. For example, the teacher can let students read a short description and draw or use stickers to create a picture. Teachers can also ask their students to use the vocabulary and construct their photographs. And after that, teachers can ask them to make a mind map of families of words in reading. Another way of studying vocabulary is using a background image on the screen with words and asking students to drag and drop or label to complete the picture. Moreover, studying vocabulary on Microsoft Whiteboard can be applied to all topics.

\section{CONCLUSION}

When being taught the speaking skill in the online environment with the support of an interactive whiteboard integrated with MS-Teams, non-majored students will have better interaction with their teacher (and peers) and, consequently, greater learning motivation and concentration, even with big-sized classes. The students' fluency in their speaking performance will be enhanced by improving those.

However, further research should be carried out to find out how to improve the students' speaking fluency by improving the students' pronunciation and mistake correction via the use of MS-Team as it is one of the most effective ways to lecture in real-time online learning class nowadays.

\section{REFERENCES}

[1] Colorful, V., \& Abaidoo, N.. The role of elearning, advantages and disadvantages of its adoption in higher education. International Journal of Instructional Technology and Distance Learning. 12(1)(2015) 29-42.

[2] Barrette, C.M.. Students' preparedness and training for CALL. CALICO Journal. 19(1)(2001) $5-36$.
[3] Bender,T.. Discussion-based online teaching to enhance student learning: Theory, practice and assessment. Stylus Publishing, LLC. (2012).

[4] Bernard, R. M., Abrami, P. C., Lou, Y., Borokhovski, E., Wade, A., Wozney, L., ... Huang, B.. How Does Distance Education Compare With Classroom Instruction? A MetaAnalysis of the Empirical Literature. Review of Educational Research. 74(3)(2004) 379-439.

[5] Bernard, R. M., Abrami, P. C., Borokhovski, E., Wade, A., Tamim, R., Surkes, M. A., et al.. A meta-analysis of three interaction treatments in distance education. Review of Educational Research. 79(3)(2009) 1243-1289. doi: $10.3102 / 0034654309333844 \mathrm{v} 1$.

[6] Bracher, J.. A survey of online teaching by nativespeaker English instructors at Japanese universities. JALT CALL Journal. 9(3) (2013) $221-$ http://journal.jaltcall.org/articles/9_3_Bracher.pd f. Accessed 31 July 2016.

[7] Broadbent, J.. Comparing online and blended learner's self-regulated learning strategies and academic performance. The Internet and Higher Education. 33(2017) 24-32.

[8] Burdman, P..Cyber U. Anaheim (California) Orange County Register, September 13, sec. 1, p. 9. (1998).

[9] Burrows, T., Stepanczuk, D.. Gauge of readiness for Internet based language learning: An 800 pound GORILLA. Jaltcall journal. 9(2) (2013)197-217

[10] Butler-Pascoe, M. E., \& Wiberg, K. W. Technology and teaching English language learners. (2003)

[11] Bygate, M.. Speaking, Oxford: Oxford University Press. (1987)

[12] Bygate, M., \& Samuda, V.. Integrative planning through the case of task-repetition. In R. Ellis (Ed.), Planning and task performance in a second language. (2005) 37-74.

[13] Carlson, R. A., Sullivan, M., \& Schneider, W.. Practice and working memory effects in building procedural skill. Journal of Experimental Psychology: Learning, memory, and Cognition. 15 (1989) 517-526.

[14] Davis, F.D., Bagozzi, R.P., \& Warshaw, P.R.. User acceptance of computer technology: A comparison of two theoretical models. Management Science. 35(8) (1989) 982-1003 
[15] Damaris E. Silalahi. Correlation between Students' Learning Motivation and speaking Competence at SFL FKIP University HKBP Nomensen. International Journal of English Literature and Social Sciences (IJELS). 3(6)(2018)992-995 https://dx.doi.org/10.22161/ijels.3.6.11

[16] Duran, A. \& Cruz, M.. The interactive whiteboard and foreign language learning: A case study. Porta Linguarum. 15 (2011) 211-231.

[17] Goertler, S.. Hybridizing the curriculum: Needs, benefits, challenges, and attitudes. In R. Oxford \& J. Oxford (Eds.), Second language teaching and learning in the Net generation.(2009) 53-64.

[18] Goertler, S., Bollen, M., \& Gaff, J.. Students' readiness for and attitudes toward hybrid FL instruction. CALICO Journal.29(2)(2012)297320.

https://journals.equinoxpub.com/index.php/CALI CO/article/download/23730/22585. Accessed 5 July 2016.

[19] Hai-Jew, S.. Evaluating "MS Teams" for Teaching and Learning. C2C Digital Magazine. 1(13)(2020) 7.

[20] Housen, A., Kuiken, F., \& Vedder, I. (Eds.). Dimensions of $L 2$ performance and proficiency: Complexity, accuracy and fluency in SLA. 32 (2012)

[21] Hung, M.L., Chou, C., Chen, C.H., \& Own, Z. Y.. Learner readiness for online learning: Scale development and student perceptions. Computers \& Education. 55(2010) 1080-1090.

[22] Karsenti, T.. The interactive whiteboard: uses, benefits, and challenges. A survey of 11,683 students and 1,131 teachers. Canadian Journal of Learning and Technology. 42(5) (2016) 1-22.

[23] Keengwe, J., \& Kidd, T. T.. Towards best practices in online learning and teaching in higher education. MERLOT Journal of Online Learning and Teaching.6(2) (2010), 533-541.

[24] Lamb, T. E. R. R. Y., \& Little, S. A. B. I. N. E..Assessment for autonomy, assessment for learning, and learner motivation: Fostering learner identities. Classroom-based Assessment in L2 Contexts. (2016) 184-206.

[25] McCarty, S.. Theorizing and realizing the globalized classroom. In A. Edmundson (Ed.), Globalized e-learning cultural challenges. (2007) 90-115.
[26] McCutcheon, K., Lohan, M., Traynor, M., \& Martin, D.. A systematic review evaluating the impact of online or blended learning vs. face-toface learning of clinical skills in undergraduate nurse education. Journal of Advanced Nursing. $71(2)$ (2015) 255-270.

[27] Murray, A., \& Blyth, A.. A survey of Japanese university students' computer literacy levels. JALT CALL Journal. 7(3) (2011)307318. http://journal.jaltcall.org/articles/7_3_Murra y.pdf. Accessed 17 July 2016.

[28] Nation, I. S. P.. Improving speaking fluency. System. 17(3) (1989) 377-384.

[29] Nawaz.A, Bibi. N, Sheikh. A, Bilal, H.A, Rehman. A.. The Role of Motivation in Learning English Language for Pakistani Learners. International Journal of Humanities and Social Science. 4(2014) 254- 258.

[30] Namaziandost, E., Hashemifardnia, A., \& Shafiee, S.. The impact of opinion-gap, reasoning-gap, and information-gap tasks on EFL learners' speaking fluency. Cogent Social Sciences, 5, (2019)1630150. doi:10.1080/23311886.2019.1630150

[31] Nguyen, T.. The effectiveness of online learning: beyond no significant difference and future horizons. MERLOT Journal of Online Learning and Teaching. 11(2) (2015) 309-319.

[32] Oz, H.. Teachers' and students' perceptions of interactive whiteboards in the English as a foreign language classroom. TOJET: The Turkish Online Journal of Education Technology. 13(3) (2014)126-147.

[33] Richard, J.C., \& Schmidt, R.. Longman dictionary of language teaching and applied linguistics. 3 (2002).

[34] Russell, T. L.. The no significant difference phenomenon: A comparative research annotated bibliography on technology for distance education: As reported in 355 research reports, summaries and papers. (1999).

[35] Salmon, G. E-tivities: The key to active online learning. (2013).

[36] Schmidt, R..Attention, awareness, and individual differences in language learning. Perspectives on individual characteristics and foreign language education. 6 (2012) 27.

[37] Siedentop, D., \& Tannehill, D. Developing Teaching Skills in Physical Education. 4 (2000). 
[38] Shernoff, D. J., Csikszentmihalyi, M., Schneider, B., \& Shernoff, E. S.. Student engagement in high school classrooms from the perspective of flow theory. In Applications of flow in human development and education. (2014) 475-494).

[39] Shih, C.C. \& Gamon, J.. Web-based Learning: Relationships among Student Motivation, Attitudes, Learning Styles, and Achievement. Journal of Agricultural Education. 42(4) (2001) 12-20. Retrieved December 30, 2020 from https://www.learntechlib.org/p/94180/.

[40] Smith, P.,. Learning preferences and readiness for online learning. Educational Psychology. 25(1) (2005) 3-12

[41] Shudong, W., Higgins, M., \& Shima, Y.. Training English pronunciation for Japanese learners of English online. JALT CALL Journal. 1(1)(2005) 39-47. http://journal.jaltcall.org/articles/1_1_Wang.pdf. Accessed 17 July 2016.

[42] Simpson, O.. Supporting students for success in online and distance education. (2013).

[43] Simpson, O.. Supporting students in online, open and distance learning. (2018).

[44] Stephenson, J. (Ed.). Teaching \& learning online: new pedagogies for new technologies. (2018).

[45] Vonderwell, S., \& Zachariah, S.. Factors that influence participation in online learning. Journal of Research on Technology in education. 38(2) (2005) 213-230.

[46] Stone, K.. 10 Best Online Whiteboards for Team Collaboration in 2020. (2020). Retrieved from https://getvoip.com/blog/2020/06/04/best-onlinewhiteboards/

[47] Szpunar, K. K., Moulton, S. T., \& Schacter, D. L. Mind wandering and education: from the classroom to online learning. Frontiers in Psychology. 4 (2013) 495.

[48] Turel, Y. K., \& Johnson, T.E.. Teachers' belief and use of interactive whiteboards for teaching and learning. Educational Technology \& Society. 15(1) (2012) 381-394.

[49] Xu, H. L. \& Moloney, R.. Perceptions of interactive whiteboard pedagogy in the teaching of Chinese language. Australian Journal of Educational Technology. 27(2) (2011) 307-325.

[50] Yang, Y. T. C., \& Chang, C. H. Empowering students through digital game authorship: Enhancing concentration, critical thinking, and academic achievement. Computers \& Education. 68 (2013) 334-344.

[51] Yanez, L. \& Coyle, Y.. Children's perceptions of learning with an interactive whiteboard. ELT Journal. 65(4) (2010) 446-457.

[52] Young, J. R.. Rethinking the Role of the Professor in an Age of High-Tech Tools. Chronicle of Higher Education. 44(6) (1997).

[53] Wanstreet, C. E.. Interaction in online learning environments: A review of the literature. Quarterly Review of Distance Education. 7(4) (2006) 399.

[54] Winke, P., \& Goertler, S.. Did we forget someone? Students' computer access and literacy for CALL. CALICO Journal. 25(3) (2008) 482509

[55] Winke, P. M., \& Goertler, S..An introduction to distance language learning. Opening doors through distance language education: Principles, perspectives, and practices. (2008) 1-10.

[56] Winke, P., Goertler, S., \& Amuzie, G. L. Commonly taught and less commonly taught language learners: Are they equally prepared for CALL and online language learning? Computer Assisted Language Learning.23(3)(2010)53-70. doi:10.1080/09588221.2010.486576. 